\title{
IONIZING EVOLVING IMPACT ON THE FOODSTUFF SAFETY INDICATOR
}

\author{
Влияние ионизирующего излучения на показатели \\ безопасности пищевых продуктов
}

Tikhonov S.L., Timakova R.T., Muratov A.A. Тихонов С.Л., Тимакова Р.Т., Муратов А.A.

\author{
Keywords: \\ radiation; \\ radiation dose; \\ ionizing evolving; \\ spices; \\ chilled meat
}

Ключевые слова:
облучение;
доза облучения;
ионизирующее
излучение;
пряности;
мясо охлажденное

\begin{abstract}
The Russian integration into the global practice of using radiation technology confirms the requirement for radiobiological control to unveil the foodstuff radiation fact, establishing databases on the foodstuff radiation sensitivity aimed at determining the optimal radiation doses and its effect on the expiry date and products quality. Authors have conducted the study on the Ekaterinburg consumer market in order to detect the presence of radiation-processed foodstuff - spices (The National State Standard of the RF 332712015 "Dry Spices, Herbs and Vegetable Seasonings. Guideline for Radiation Targeted of the Pathogens and Other Microorganism Abatement"; dated January 01, 2017) and chilled meat (The National State Standard of the RF 33820-2016 "Fresh and Frozen Meat. Guideline for Radiation Targeted of the Parasites, Pathogens and Other Microorganism Abatement"; dated July 01, 2017). Experimental results proved the presence of the imported radiation-processed spices, particularly ground black pepper (radiation dose of 10-11 kGy), ground bird's eye chili pepper (2-3 kGy) and ground hot chili pepper (4-6 kGy). Russian chilled meat (beef, pork, and poultry) and some imported spices (ground white pepper, turmeric) were not previously the subject of ionizing evolving. Consumers have no information about the foodstuff processing with ionizing evolving.
\end{abstract}

\section{Реферат}

Интегрирование России в общемировую практику использования радиационных технологий обусловило необходимость радиобиологического контроля для выявления факта облучения пищевых продуктов, создания банка данных о радиационной чувствительности пищевых продуктов с целью определения оптимальных доз облучения и изучения их влияния на сроки хранения и качество продуктов. Авторами проведено исследование на потребительском рынка г. Екатеринбурга для выявления присутствия и (или) отсутствия радиационно-обработанных пищевых продуктов: пряностей (ГОСТ 33271-2015 «Пряности сухие, травы и приправы овощные. Руководство по облучению в целях борьбы с патогенными и другими микроорганизмами»; введен с 1 января 2017 г.) и мяса охлажденного (ГОСТ 33820-2016 «Мясо свежее и мороженное. Руководство по облучению для уничтожения паразитов, патогенных и иных микроорганизмов» вводится в качестве национального стандарта с 1 июля 2017 г.). Полученные данные свидетельствуют о наличии на потребительском рынке г. Екатеринбурга радиационно-обработанных пряностей импортного производства, в частности перца черного молотого (доза облучения 10-11 кГр), чили жгучего молотого (2-3 кГр) и чили острого молотого (4-6 кГр). Мясо охлажденное (говядина, свинина, птица) отечественного производства и ряд пряностей импортного производства (перец белый молотый, куркума) не были ранее подвергнуты воздействию ионизирующего излучения. До потребителей не доведена информация об обработке пищевых продуктов ионизирующим излучением. 
Relevance

The loss of food raw materials and foodstuff arises during production; processing and storage connected with the storage failure modes can reach 30 $40 \%$ of total production. The foodstuff sterilization by ionizing radiation allows to increase its expiry date.

In 1970 in Paris, 19 states approved the International program in the field of food radiation. Committees of the FAO, the WHO, the IAEA and the Multinational advisory group on foodstuff radiation considered the problem of the foodstuff sterilization. Radiation technologies are actively used abroad so spices, wheat, wheat flour and potatoes have been allowed to irradiate since 1985; poultry meat - since 1992; chilled and frozen red meat (beef, lamb, and pork) - since 1999. However, the necessity of the radiation technologies implementation in the food industry is widely discussed among scientists. Domestic and foreign researchers continue studies on establishing causal relationships between radiation dose and the nutritional foodstuff value, and expiry date, defining as basis the radiated foodstuff safety for humans. According to scientists, on the one hand, radiation is one of the best methods of food preservation to extend the foodstuff and food raw materials expiry date because of the dose shortterm impact on the product. On the other hand, the biological processes violate in foodstuff; free radicals arouse while processing and interacting with other molecules in the food system lead to the molecular structure change of the organic substances. lonizing evolving affects the physico-chemical properties change of the products, leads to a quality disruption of foodstuff and food raw materials, as well as to changes in the products organoleptic properties when using high doses (color and consistency changes).

[6] found that foodstuff radiation processing practically did not change the amino acid composition; carbs converted from more to less complex compounds mainly by disruption glucosidic bonds. In some cases, there might be the interaction between reduced carbohydrates and amino acids with the melanoid formation. Irradiated foodstuff showed the lipids oxidative processes with the peroxide compounds formation.

Applyingradiationdose of $0,1 \mathrm{kGy}$ forspicesisestablished to affect only $0,004 \%$ of the amino acids [11].

Spices (black pepper, allspice, coriander, juniper, caraway, cinnamon, badian, mustard, laurel lea, paprika, rosemary, garlic, ginger, thyme, cardamom) used in the meat products production initially go through seeding with microorganisms that are relevant to its place of growth.

The authors established that when the radiation dose was of $4 \mathrm{kGy}$ coliform bacteria in black and red pepper died completely, Penicillium and spoilage yeast reduced by $100 \%$ and $96 \%$, respectively. Until $1,1 \times 106$ CFU/g spore-forming bacteria (processing efficiency accounted for $94 \%$ ) remained in the black pepper after radiation by dose of $10 \mathrm{kGy}$. Studying the ionizing evolving effect on spore-forming bacteria in the red pepper showed the effectiveness of only $48 \%$ that might be due to the high resistance of this microorganisms group [12].

The scientists in their work have found that radiation overdose in meat could lead to free radicals and radiotoxins formation on bones $[3 ; 8]$.

The proposed hybrid method of the radiation conservation of minced pork lean tissue, that combines irradiating by the electron beam in the radurization mode and processing by $40 \%$ ethanol, as well as the use of ascorbic acid as an antioxidant, is applied to extend anaerobic expiry date of meat products at low positive temperature $\left(4^{\circ} \mathrm{C}\right)$ in $5-6$ times while keeping quality of all organoleptic and microbiological indicators $[4 ; 5]$.

When conducting experimental studies on chicken-broilers meat processing by ionizing evolving authors discovered the following: the sterilization by ionizing evolving in doses of 2.5 and $6 \mathrm{kGy}$ is recommended to increase the expiry date of chicken-broilers meat; meat exposed to ionizing evolving at doses of 2.5 and $6 \mathrm{kGy}$ is allowed to be used in food production purposes without restrictions [1].

[7] proved the possibility of using smaller systems with different regimes of $\gamma$-radiation for sterilization of plant and animal origin products (spices, dried and fresh vegetables).

Consumers have negative attitude towards irradiated foodstuff. On the unscientific understanding of the radioactivity phenomenon level there is confusing of two definitions: the radiation technology of energy and non-energy origin, and radioactively contaminated and radiation-processed products. Followers of the radiation technologies use argue that the radionuclides activity that may occur in the human body while consuming irradiated food is significantly less than the average total activity of natural radionuclides presented in every human body $[9,10]$. There are also separate data on the risk of cancer among humans eating irradiated food.

In different countries, the maximum allowed foodstuff radiation dose varies, so in the US it is 30 $\mathrm{kGy}$, in Belgium and the Netherlands - $10 \mathrm{kGy}$, in France $-11 \mathrm{kGy}$, respectively.

In accordance with the decision of the Presidium of the Russian Presidential Council for Economy Modernization and Innovative Development dated December 11, 2014, the application of foodstuff and agricultural raw materials radiation processing aimed at phytosanitary treatment; destroying 
or reducing the pathogenic microorganisms and parasites number, and vegetative micro-organisms causing spoilage; extending expiry date is allowed in our country. In recent years, the national regulatory framework, developed taking into account the main existing normative provisions of international standards on radiation technology, acceptable doses and dosimetry methods, has been actively evolving. The use of radiation technologies in the food industry depends on the ability to include it in production cycles, competitiveness and economic worthwhileness.

According to The National State Standard of the RF 33271-2015 "Dry Spices, Herbs and Vegetable Scasonings. Guideline for Radiation Targeted of the Pathogens and Other Microorganism Abatement" came into legal force January 01, 2017 on the Russian Federation territory, the minimum radiation dose from 3 to 6 kGy destroys fungi (including Penicillium). Vegetative bacteria reduces the size or destroys by the minimum dose from 4 to $7 \mathrm{kGy}$, and spore-forming bacteria reduces the numbers till acceptable level at the lowest dose from 8 to $15 \mathrm{kGy}$. Table 1 presents suggested minimum doses ranges for these spices and herbs.

\section{Table 1}

Minimum Dose for Some Spices, Herbs and Vegetable Seasonings

\begin{tabular}{|l|l|}
\hline Foodstuff & Minimum Dose, kGy \\
\hline Allspice & from 4 to 8 \\
\hline Basil & from 6 to 8 \\
\hline Cumin & from 3 to 8 \\
\hline Cardamom & from 4 to 8 \\
\hline Celery seed & from 4 to 8 \\
\hline Cinnamon & from 3 to 8 \\
\hline Coriander & from 4 to 8 \\
\hline Fennel & from 6 to 12 \\
\hline Garlic powder & from 6 to 12 \\
\hline Ginger & from 4 to 8 \\
\hline Marjoram & from 6 to 12 \\
\hline Muscat & from 4 to 8 \\
\hline Onion powder & from 7 to 15 \\
\hline Oregano & from 6 to 12 \\
\hline Paprika & from 3 to 8 \\
\hline Black Pepper & from 6 to 12 \\
\hline Red Pepper & from 3 to 8 \\
\hline Thyme & from 6 to 12 \\
\hline Turmeric & from 3 to 8 \\
\hline
\end{tabular}

Alimentarius Code determines the food radiation to be performed safely and correctly in accordance with all Code relevant standards and hygiene rules and regulations with completed transport documentation; to comply with the valid radiation norms and to have the right mark. Food radiation is justified only if it satisfies the technological requirements and (or) is aimed at protecting consumer health. The Code sets the maximum dose of absorbed radiation - not more than $10 \mathrm{kGy}$ except the situation when it is necessary to obtain an acceptable the technological process result [2].

For foodstuff radiation processing three main types of radiation are allowed: radiation of the accelerated electrons with energy up to $10 \mathrm{MeV}$; X-ray (braking) radiation with energy up to $5 \mathrm{MeV}$ (radiation sources are radionuclides $60 \mathrm{Co}$ and $137 \mathrm{Cs}$ ).

According to the WHO recommendations, it is obligatory for all manufacturers to inform consumers through labels on packaging "Treated by radiation" and a sign on the package "radura" (Fig. 1).

Dissemination of radiation technologies requires advanced studying techniques of food raw materials and foodstuff safety. The most effective is to consider the electron paramagnetic resonance (EPR) method discovered in 1944 by Y. K. Zavoisky. Currently, the EPR method is widely used as one of the fundamental methods to study various substances and processes in physics, chemistry, biology, geology and other sciences. The authors apply the ESR method to evaluate the radiation foodstuff safety. To identify food raw materials and foodstuff processed by ionizing evolving one can use the EPR spectrometer.

Various companies present imported foodstuff on the Russian consumer market. According to the results of 2016 the turnover of food and agricultural raw materials in the RF external turnover structure accounts for $12.5 \%$. Experts estimate the domestic producers share on the Russian spices market at only $20-30 \%$. The rest arrives from China, India, Vietnam, Bangladesh, Turkey. Those spices mostly incur ionizing evolving.

Purpose: to ascertain the radiation/unirradiation fact among samples of imported spices and domestic chilled meat.

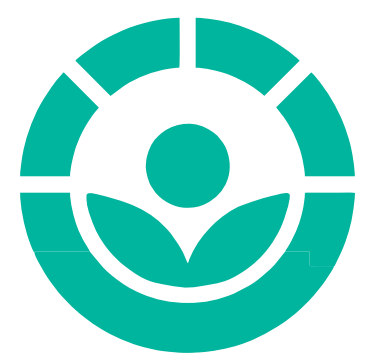

Figure 1. Standard Mark for Radiated Products 


\section{The Objects and Methods of the Research}

\section{Materials:}

- samples of imported spices: ground black pepper (Vietnam), ground white pepper (Sweden), turmeric (India), bird's eye chili pepper (Thailand), ground hot chili pepper (India), curry (India);

- samples of meat and bone prepared food of domestic production.

- Ekaterinburg consumer market presents all analyzed foodstuff samples.

Sampling and testing samples preparing were carried out according to The National State Standard of the RF 52529-2006 "Meat and Meat Products. Electron Paramagnetic Resonance Method for Irradiated Meat and Meat Products Containing Bones Detection" and The National State Standard of the RF 31672-2012 "Foodstuff. Electron Paramagnetic Resonance Method for Irradiated Foodstuff Containing Cellulose Detection".

The study was fivefold conducted. Researchers used the EPR spectrometer "Labrador Expert series" of the $\mathrm{X}$-range as working dosimeter.

The authors applied reference sample (high stability reference) for signals comparison: on the PMC amount measure on the manganese oxide basis. The study was carried out at the microwave frequency close to $9200 \mathrm{MHz}$; between different magnetic field ranges (with 3280 hs center); variable time conversion, modulation amplitude and gain ratio. The microwave power was set at the level of $4-8 \mathrm{dBm}$ by testing for normalization of signal/noise index.

\section{Research Results and Its Discussion}

By the weak signal and the EPR spectra characteristic absence, the researchers revealed while testing samples of ground white pepper, turmeric and beef, pork and poultry bone tissue that the samples were not previously exposed to ionizing evolving.

While studying authors established that ground black pepper samples (Fig. 2) went under radiation by a dose of 10-11 kGy.

The main EPR signal parameters of the ground black pepper samples: the g-factor is 2.0040 , the peak amplitude is 2.49 e-04 relative units, and the signal width is $14 \mathrm{hs}$.

The research of hot chili pepper samples (Fig. 3) revealed the typical EPR multiple-component spectra so called multiplet with moderate signal indicating earlier ionizing evolving dose appliance of 2-3 kGy.

In the magnetic field of 3270-3280hs there are a peak with an amplitude of 1.03 e-05 relative units, 2hs-width and g-factor equal 2.0053; two signals with a small amplitude: 1,16 e-06 relative units and 8.96 e-06 relative units with $91=2.0027$ and $g 2=2.0044$. The signal/noise ratio is very low.

The figure 4 shows that the bird's eye chili pepper samples were irradiated by the dose of 4-6 kGy. So, $g$-factor equals to 2.0043 , the amplitude peak is 3.03 e- 05 relative units, spectral width is 8 hs, the ratio of signal/noise index is low.

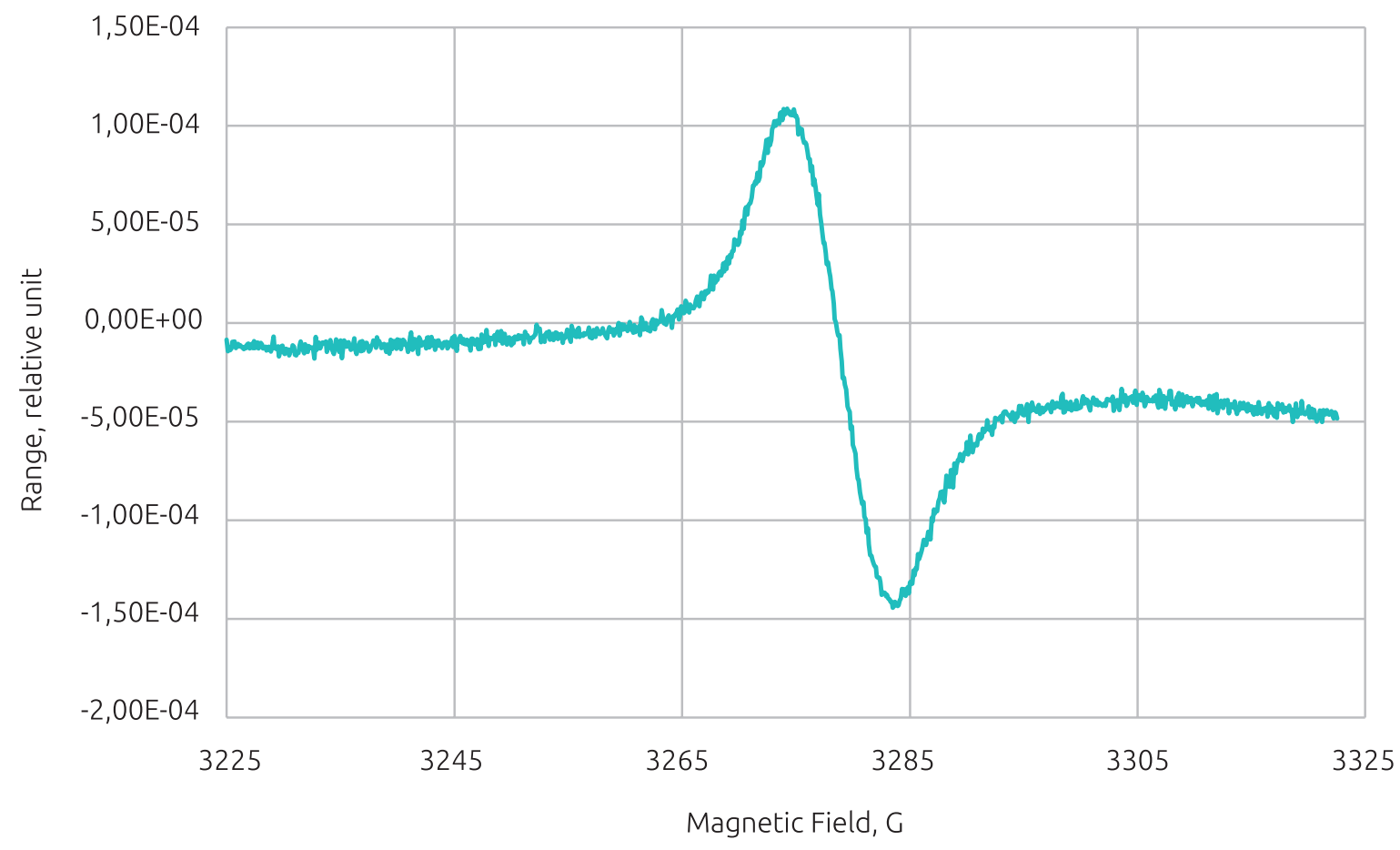

Figure 2. Ground Black Pepper Facilities 


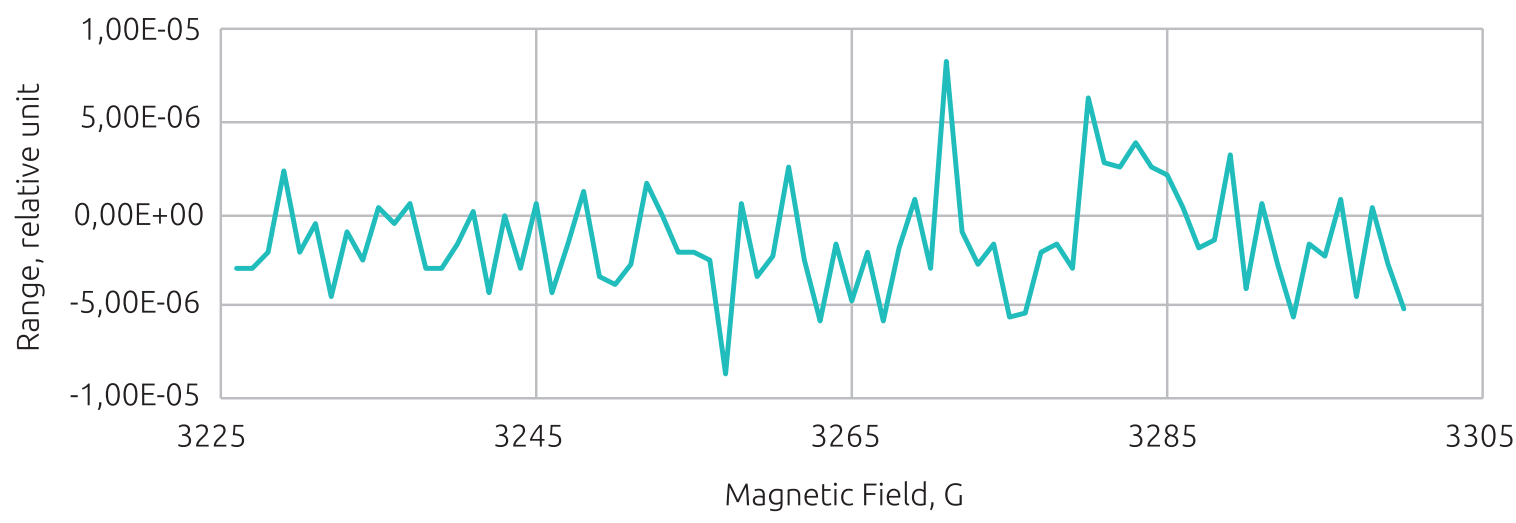

Figure 3. Hot Chili Pepper Facilities

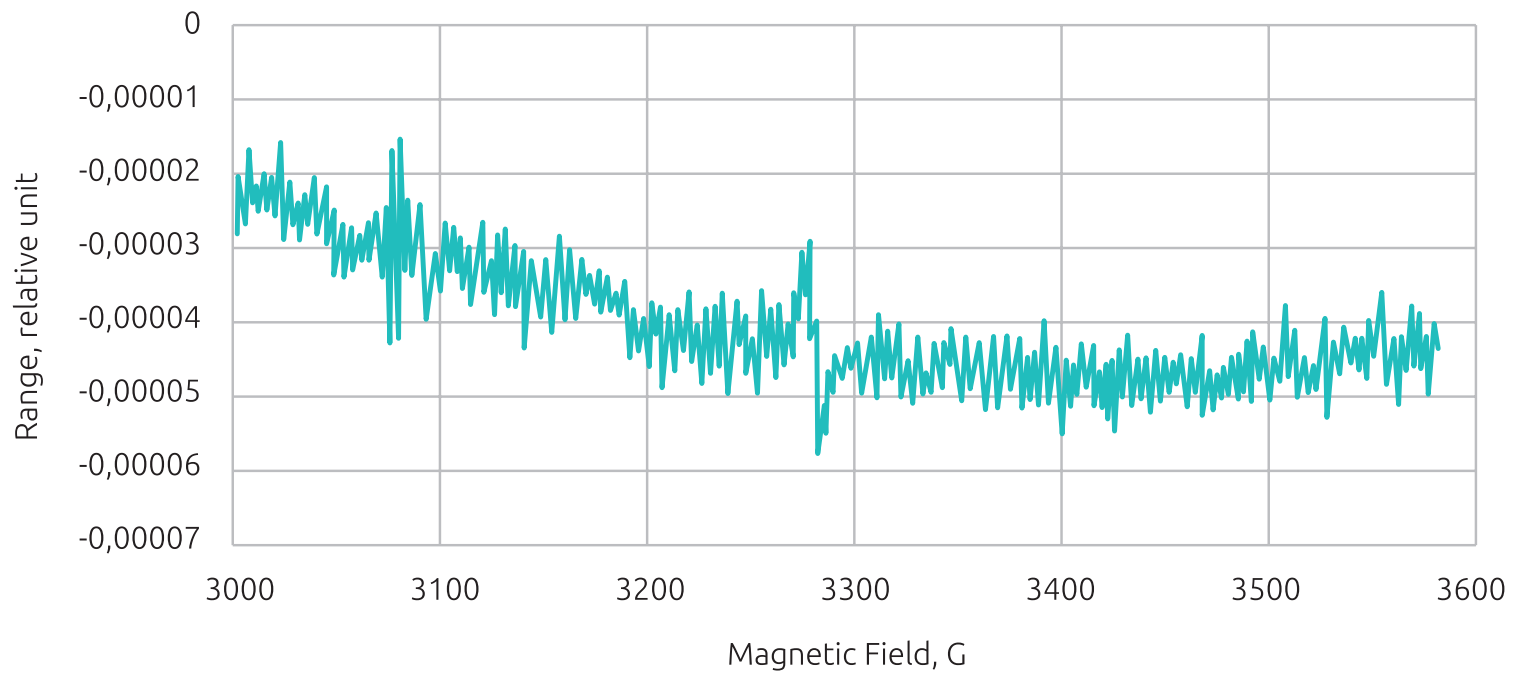

Figure 4. Bird's Eye Chili Pepper Facilities

Findings

Thus, as a result of the EPR method experimental studies scientists ascertain that domestically produced meat-and-bone processed products presented on the Ekaterinburg consumer market are not submitted by ionizing evolving.

Some imported spices, particularly ground black pepper, bird's eye chili pepper, ground hot chili pepper are subjected to the ionizing evolving of different doses 10-11, 2-3, and 4-6 kGy, respectively. Irradiated products show on the spectrometer the same spectra amount depending on the type of a product. The EPR signal intensity depends on the radiation dose. There is no information about the fact of food ionizing evolving on the consumer packaging.

\section{Conclusion}

The radiation technologies appliance in the technological food production process determines the necessity of radiological control at all stages of the food chain. However, it is obligatory to conduct further studies in order to determine optimal food radiation doses and evaluate irradiated food safety.

\section{Bibliography}

1. Kaziahmedov A.S. Veterinarno-sanitarnaja ocenka kachestva i bezopasnosti mjasa cypljat-brojlerov pri obrabotke ionizirujushhim izlucheniem: dis... kand. veterin. nauk. M.: MGUPP, 2012.124 s.

2. Codex Alimentarius. Obluchennye produkty pitanija: per. s angl. M.: Izd-vo "Ves' mir», 2007. 24 s.

\section{Библиографический список}

1. Казиахмедов А.С. Ветеринарно-санитарная оценка качества и безопасности мяса цыплят-бройлеров при обработке ионизирующим излучением: дис... канд. ветерин. наук. М.: МГУПП, 2012. 124 c.

2. Codex Alimentarius. Облученные продукты питания: пер. с англ. М.: Изд-во «Весь мир», 2007. 24 с. 
3. Kostenko Ju.G., Shurduba N.A., Shagova T.S., Telegina M.D., Filatov V.I. Primenenie ionizirujushhih izluchenij dlja uluchshenija sanitarno-mikrobiologicheskih pokazatelej mjasa i mjasnyh produktov. M.: Mjasomolochnaja prom-t', 1992. 32 c.

4. Orehova S.M., Nechiporenko A.P. Radurizacija myshechnoj tkani svininy // Nauchnyj zhurnal NIU ITMO. Ser.: Processy i apparaty pishhevyh proizvodstv. 2014. № 1. S. 273-283.

5. Orehova S.M. Radiacionno-himicheskoe konservirovanie myshechnoj tkani svininy: dis...kand. tehn. nauk. SPb, 2014. $175 \mathrm{~s}$.

6. Radiacionnaja tehnologija v sel'skom hozjajstve i pishhevoj promyshlennosti / pod obshh. red. G.V. Koz'mina, S.A. Geras'kina, N.I. Sanzharovoj. Obninsk: VNIIRAJe, 2015. $400 \mathrm{~s}$.

7. Sanzharova N.I., Pavlov A.N., Pimenov E.P., Koz'min G.V., Kobjalko V.O., Saruhanov V.Ja. Radiacionnaja obrabotka produktov zhivotnogo i rastitel'nogo proishozhdenija v celjah mikrobiologicheskoj bezopasnosti // Radiacionnye tehnologii: dostizhenija i perspektivy razvitija: trudy nauch.-prakt. konf. (Jalta, 21-23 oktjabrja 2014 g.). M, 2015. Sm.: Voprosy atomnoj nauki i tehniki. Ser.: Tehnicheskaja fizika i avtomatizacija. Vyp. 71. S. 65-72.

8. Chizh T.V., Koz'min G.V., Poljakova L.P., Mel'nikova T.V.Radiacionnaja obrabotka kak tehnologicheskij priem $v$ celjah povyshenija urovnja prodovol'stvennoj bezopasnosti // Vestnik Rossijskoj akademii estestvennyh nauk. 2011. № 4. S. 44-49.

9. Dosimetry for food irradiation. Vienna: International Atomic Energy Agency. Technicalreportseries, ISSN 0074-1914. 2002. № 409. $161 \mathrm{p}$.

10. Natural and induced radioactivity in food. IAEA-TECDOC-1287. Vienna: IAEA, 2002. $136 \mathrm{p}$.

11. Pillai S. D., Shayanfar S. Electron Beam Technology and Other Irradiation Technology Applications in the Food Industry // Topics in Current Chemistry. 2017. Vol. 375. № 1. P. 6.

12. Ukai M. Electron spin resonance spectroscopy in food radiation research // JEOL News. 2004. Vol. 39. № 1. P. $24-27$.
3. Костенко Ю.Г., Шурдуба Н.А., Шагова Т.С., Телегина М.Д., Филатов В.И. Применение ионизирующих излучений для улучшения санитарно-микробиологических показателей мяса и мясных продуктов. М.: Мясомолочная пром-ть, 1992. 32 с.

4. Орехова С.М., Нечипоренко А.П. Радуризация мышечной ткани свинины // Научный журнал Ниу итМО. Сер.: Процессы и аппараты пищевых производств. 2014. № 1. С. 273-283.

5. Орехова С.М. Радиационно-химическое консервирование мышечной ткани свинины: дис...канд. техн. наук. СПб, 2014. 175 с.

6. Радиационная технология в сельском хозяйстве и пищевой промышленности / под общ. ред. Г.В. Козьмина, С.А. Гераськина, Н.И. СанЖаровой. Обнинск: ВНИИРАЭ, 2015. 400 с.

7. Санжарова Н.И., Павлов А.Н., Пименов Е.П., Козьмин Г.В., Кобялко В.О., Саруханов В.Я. Радиационная обработка продуктов животного и растительного происхождения в целях микробиологической безопасности // Радиационные технологии: достижения и перспективы развития: труды науч.-практ. конф. (Ялта, 21-23 октября 2014 г.). М, 2015. См.: Вопросы атомной науки и техники. Сер.: Техническая физика и автоматизация. Вып. 71. C. 65-72.

8. Чиж Т.В., Козьмин Г.В., Полякова Л.П., Мельникова Т.В.Радиационная обработка как технологический прием в целях повышения уровня продовольственной безопасности // Вестник Российской академии естественных наук. 2011. № 4. С. 44-49.

9. Dosimetry for food irradiation. Vienna: International Atomic Energy Agency. Technicalreportseries, ISSN 0074-1914. 2002. № $409.161 \mathrm{p}$.

10. Natural and induced radioactivity in food. IAEA-TECDOC-1287. Vienna: IAEA, 2002.136 p.

11. Pillai S. D., Shayanfar S. Electron Beam Technology and Other Irradiation Technology Applications in the Food Industry // Topics in Current Chemistry. 2017. Vol. 375. № 1. P. 6.

12. Ukai M. Electron spin resonance spectroscopy in food radiation research // JEOL News. 2004. Vol. 39. № 1. P. 24-27.

\section{Tikhonov Sergei Leonidovich \\ Тихонов Сергей Леонидович}

тел./Phone: (343) 221-27-66 E-mail: tihonov75@bk.ru

\section{Timakova Rosa Temerjyanovna Тимакова Роза Темерьяновна \\ тел./Phone: (343) 221-17-26 E-mail:trt64@mail.ru}

\section{Muratov Ascar Aronovich Муратов Аскар Аронович}

Тел./Phone: (7142) 28-02-55 E-mail: naukakipu@kineu.kz
Doctor of Technical Science, Professor, Head of the Food Engineering Department Ural State University of Economics 620144, Russia, Ekaterinburg, 8 March St. / Narodnoy Voli St., 62/45

Доктор технических наук, профессор, заведующий кафедрой пищевой инженерии Уральский государственный экономический университет 620144, РФ, г. Екатеринбург, ул. 8 Марта/Народной Воли, 62/45

Candidate of Agricultural Science, Associate Professor of the Tourism Business and Hospitality Department

Ural State University of Economics

620144, Russia, Ekaterinburg, 8 March St. / Narodnoy Voli St., 62/45

Кандидат сельскохозяйственных наук, доцент кафедры туристического бизнеса и гостеприимства

Уральский государственный экономический университет 620144, РФ, г. Екатеринбург, ул. 8 Марта/Народной Воли, 62/45

Candidate of Agricultural Science, Pro-rector for research Kostanay Engineering and Economics University n.a. M.Dulatov 110001, Kazakhstan, Kostanay, Chernyschevskogo Str., 59

Кандидат сельскохозяйственных наук, проректор по научной работе Костанайский инженерно-экономический университет им. М. Дулатова 110001, Казахстан, г. Костанай, ул. Чернышевского, 59 